\title{
STUDIES ON CARBONIFEROUS INSECTS OF COMMENTRY, FRANCE: PART III. THE CALONEURODEA
}

\author{
By F. M. Carpenter \\ Harvard University
}

\section{Introduction}

This is the third in a series of papers redescribing certain of the Carboniferous insects of the Commentry Basin, France. ${ }^{1}$ It treats those Commentry species which now appear to belong to the order Caloneurodea. This extinct order was erected by Martynov in 1938 for the Carboniferous family Caloneuridae and for related families represented in Permian deposits of the USSR. It now includes additional families established by Carpenter ( 1943) for Permian species from Kansas. At the present time seven families are known in the order and of these only one, the Caloneuridae, is of Carboniferous age. The Commentry specimens are by far the most important of the Caloneuridae but Handlirsch's and Meunier's publications have given us a superficial and confused knowledge of these fossils. The present paper, which is based upon direct study of all the known Commentry material, consists of redescriptions of the fossils and a revision of their taxonomic assignments.

\section{Survey of Commentry Species}

A historical account of the Commentry collections and of the general literature on the insects was included in the first part of this series of papers (Carpenter, 1943). Among the species first described by Brongniart ( 1885 ) from the Commentry shales was a single specimen, designated Caloneura dawsoni, and assigned to the family Palaeacridiodea of the order Orthoptera. In his later monograph of the Commentry insects (1894) Brongniart included drawings of five additional specimens of dawsoni and gave a more extensive account of the genus, which he placed in the same family, designated at that time as Palaeacrididae. Handlirsch, in his 1906 treatise, established the family Caloneuridae for the genus, assigning it to the extinct order Protorthoptera.

\footnotetext{
${ }^{1}$ This research has been aided by a grant (NSF-G14099) from the National Science Foundation and by a previous grant (1938) from the Penrose Fund of the American Philosophical Society. I am indebted to the authorities of the Laboratoire de Paleontologie of the Muséum National d'Histoire Naturelle in Paris for placing at my disposal the unique collections of Commentry insects in the Muséum, both in 1938 and in 1961; and to the authorities of the British Museum (Natural History) for allowing me to examine the Commentry fossils in that institution.
} 
In I9I7 Lameere, following an examination of the Commentry fossils in the Muséum in Paris, placed in the Caloneuridae two species (similis and royeri) which Meunier had originally described (I9I I) in the order Paleodictyoptera. At about the same time (1919) Handlirsch described four more species of Caloneura, all based on the Commentry specimens illustrated in Brongniart's monograph (1894). Finally in 1925 Bolton described an additional species (subtilis) from Commentry in the British Museum (Natural History) and also figured a specimen of dawsoni included in the same collection.

As a result of my examination of all of these fossils and of additional specimens in the Muséum in Paris, not previously published upon, I propose the following classification of the Commentry Caloneurodea:

Family Caloneuridae Brongniart

Genus Caloneura Brongniart (synonym: Confusio Handlirsch) dawsoni Brongniart (synonyms: picta Handlirsch, major Handlirsch, longicornis Handlirsch, robusta Handlirsch, royeri Meunier).

Family Apsidoneuridae, new (type species, Apsidoneura flexa Carp., Permian Kansas)

Genus Homaloptila Handlirsch similis Meunier

The Commentry species which Bolton (1925) described as Caloneura subtilis (British Museum [Natural History], type 17280 ) is not, in my opinion, a caloneurid or even a member of the order Caloneurodea. However, since the poor preservation of the specimen prevents satisfactory determination even to order, I refer this species to Insecta Incertae Sedis.

\section{Family Caloneuridae Handlirsch}

Fore and hind wings similar. Sc terminating well before the wing apex; $\mathrm{CuA}$ and $\mathrm{CuP}$ very close together and nearly parallel; MP forked nearly dichotomously; 4 anal veins; cross veins numerous. Body and legs slender.

This family is known only by the genus Caloneura. The Carboniferous genera Caloneurella Carp. (Pennsylvania) and Pruvostiella Handl. (Nord, France), both of which have previously been placed here, should probably be included under Caloneurodea Incertae Sedis.

Genus Caloneura Brongniart

Caloneura Brongniart, 1885, soc. Amis Sci. Nat. Rouen., $21: 59$; 1894, Recherches Hist. Ins. Foss.: 562. Handlirsch, 1906, Foss. Ins.: 141. Carpenter, 1943, Proc. Amer. Acad. Arts Sci., $75: 69$.

Confusio Handlirsch, 1919, Denkschr. Acad. Wiss. Wien, 96:37 (New synonymy).

Fore wing with a somewhat broader costal space than the hind wing 
and with the costal space abruptly narrowed basally; hind wing narrower at base than the fore wing and with the costal margin nearly straight basally. Rs with five or six main branches, one of these usually having a short distal branch. MP usually forked, $\mathrm{CuA}$ and $\mathrm{CuP}$ unbranched.

Type species: Caloneura dawsoni Brongniart.

Confusio was based upon royeri, which Meunier described in the palaeodictyopterous genus Homaloneura, and which I consider a synonym of dawsoni.

\section{Caloneura dawsoni Brongn.}

Figure I

Caloneura dawsoni Brongniart, 1885, Soc. Amis Sci. Rouen, Bull., $21: 59$, pl.

[4], fig. 2; 1894, Recherches Hist. Ins. Foss., : 562, pl. 36, fig. 5-11.

Lameere, 1917, Mus. Nat. Hist. Natur. Bull., 23 :181. Handlirsch, 1919,

Denkschr Akad Wiss., 96:35, fig. 36. Bolton, 1925, Brit. Mus. Fossil

Insects. $2: 15$, fig. 5 .

Caloneura picta Handlirsch, 1919, ibid., p. 35, fig. 37.

Caloneura major Handlirsch, 1919, ibid., p. 35, figs. 38, 39.

Caloneura longicornis Handlirsch, 1919, ibid., p. 35, fig. 40 .

Caloneura robusta Handlirsch, ibid., p. 36, fig. 41.

Homaloneura royeri Meunier, 1911, Bull. Mus. Nat. Hist. Natur., $17: 119$, fig.

2; 1912, Ann. Paleont., 7:9, pl. 7, fig. 2; Lameere, 1917, Mus. Nat. Hist.

Natur., Bull., 23 :181.

Confusio royeri Handlirsch, 1919, Denschr. Acad. Wiss., $96: 37$, fig. 44.

This species was originally based on the single specimen figured in Brongniart's I 885 paper but was later known to Brongniart by five additional fossils, all illustrated in his Recherches ( 1894$)$. Five other specimens (here designated as $\mathrm{C}_{\mathrm{I}}-\mathrm{C}_{5}$ ), which have not previously been mentioned in the literature, are contained in the Muséum National d'Histoire Naturelle in Paris. To these may be added the specimen of dawsoni described by Bolton (1925), and the type of royeri Meunier. Since I am convinced for reasons given below that these thirteen specimens, all of which I have been able to examine, are one species (dawsoni), I have used them as a basis of the following account of this insect.

Wings (Figure I): The fore wing, which is completely preserved in several specimens, is from $45-48 \mathrm{~mm}$ in length, and from IO- $12 \mathrm{~mm}$ in width. The type specimen has a fore wing length of $45 \mathrm{~mm}$ and a width of Io mm. The hind wings of the several specimens are about the same dimensions as the fore wings but are somewhat narrowed basally. The costal area of the fore wing narrows abruptly just at the level of the separation of $\mathrm{CuP}$ and $\mathrm{IA}$. In the hind wing the costal space is not narrowed at this point, continuing its full width as far as it is preserved in all specimens. 
The general venational pattern is shown in figure $\mathrm{I}$, but this is subject to much individual variation. The subcosta terminates on the costal margin well before the end of $\mathrm{RI}_{\mathrm{I}}$; it does not extend to the apex of the wing as shown by Bolton in his drawing of a specimen in the British Museum. The number of main branches of Rs varies from 5 to 6 in the several specimens showing those veins, but usually one of these branches has a short fork, which occurs most often on R2 or R3. The branching varies in the fore and hind wings (and presumably in the right and left wings) of individual insects. In the holotype specimen $(36-5)^{2}$, for example, this fork occurs on $\mathrm{R}_{3}$ in the fore wing but on $\mathrm{R}_{2}$ in the hind wing. MP is less variable; it forks broadly at about mid-wing. In only one specimen $\left(\mathrm{C}_{4}\right)$ does either branch of $\mathrm{MP}$ clearly fork again (see figure I), but in several one or both branches
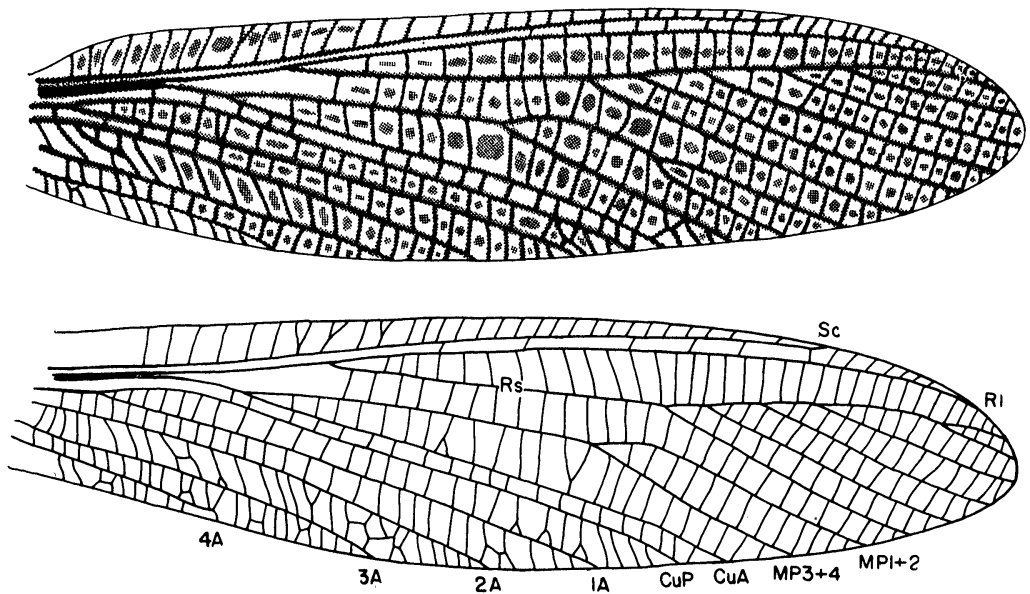

Figure 1. Caloneura dawsoni Brongn. Fore and hind wings based on the holotype and other specimens in the Muséum National, Paris. Sc, subcosta $(-) ; \mathrm{R} 1$, radius $(+)$; $\mathrm{Rs}$, radial sector (-); $\mathrm{MP} 1+2$ and $\mathrm{MP} 3+4$, branches of posterior media (-) ; 1A, 2A, 3A, 4A, anal veins.

appear to have a small, terminal fork. $\mathrm{CuA}$ and $\mathrm{CuP}$ are consistently unbranched; the divergence of $\mathrm{CuP}$ and $\mathrm{IA}$, near the base of the wing, is either shallow or somewhat broader. The four anal veins are consistently present.

The most striking characteristics of the wings of dawsoni are the

\footnotetext{
${ }^{2}$ Since the Commentry insects in the Muséum National are not numbered, I am using here the figure number on Brongniart's plates for the number of the specimen. Hence, specimen $36-5$ is the fossil illustrated on Brongniart's plate 36 , figure 5 .
} 
markings, as mentioned by Brongniart in his original description. The main vcins and most of the cross-veins are margined with dark pigment; the veins appear to be very thick but careful examination of the wing shows that the actual veins are only of usual thickness. In addition, nearly all cells of the fore wing contain a dark, irregular pigment spot. The size of the spots varies in different wings but the pattern formed in the wing as a whole is fairly constant. The hind wings appear to be without both types of these markings; at any rate, no specimens that can clearly be recognized as hind wings show them. In a few fossils some of the wings appeared blotched (as in the holotype, 36-5), but the extreme irregularity of this and its absence in other hind wings strongly indicates that it is the result of preservation.

Body structure: Very little is known of the body structure of dawsoni. Several specimens show fragments and portions of the thorax and four specimens $(36-8,36-9,36-$ IO, $36-$ I I $)$ include parts of the legs and antennae but the abdomen is entirely unknown. The legs are slender, nearly homonomous and apparently cursorial. The fore and middle legs are about $34 \mathrm{~mm}$ long and the hind legs, $45 \mathrm{~mm}$ long. The dimensions of the leg segments are given in Table $\mathrm{I}$. The tarsi of all three pairs of legs are about the same length.

$\begin{array}{lccc} & \text { Fermur } & \text { Tibia } & \text { Tarsus } \\ \text { Fore leg } & \text { I } 2 \mathrm{~mm} & \text { IO } \mathrm{mm} & \text { I } 2 \mathrm{~mm} \\ \text { Middle leg } & 12 \mathrm{~mm} & \text { I0 } \mathrm{mm} & 12 \mathrm{~mm} \\ \text { Hind leg } & 18 \mathrm{~mm} & \text { I } 5 \mathrm{~mm} & 12 \mathrm{~mm}\end{array}$

Table I. Dimensions of leg segments in Caloneura dawsoni Brongn.

The femora and tibiae of the fore and middle legs are about the same length, but the hind femur and tibia are slightly longer than those of the other pairs. The antennae are obviously long and slender, though they are not completely preserved in any fossil. In specimen 36-IO one antenna is preserved to the edge of the rock containing the specimen; the preserved part is $55 \mathrm{~mm}$ long, which is considerably in excess of the wing length.

So far as known, therefore, the body structure of dawsoni is similar to that of the best-known Permian species, Paleuthygramma tenuicornis Mart. (see Martynov, 1938b, p. 126).

Synonymy: As mentioned above, Brongniart figured in his $R e$ cherches ( I894) five speciments of dawsoni which were not known to him when he described the species in 1885 . In I919 Handlirsch, basing his conclusion on Brongniart's illustrations, established four 
additional species for these fossils: picta, major, longicornis, and robusta. No specific characteristics were even mentioned for robusta and those used for the others involved the nature of the branching of Rs. Having examined all these specimens, I cannot accept any of Handlirsch's species as valid.

Meunier's royeri, originally placed in the paleodictyopterous genus Homaloneura, was transferred to the Caloneuridae by both Lameere (1917) and Handlirsch (1919), the latter making the new genus, Confusio, for it. Meunier's drawing of the fossil (I9II, p. II9, fig. 2), although incorrect in many details, was more accurate than Handlirsch's (1919, p. 37, fig. 44), which was based solely on the small photograph contained in Meunier's later account (I9I2). The wing, which I have examined at the Paris Muséum, is characteristic of dawsoni: Rs has six branches and MP is forked as usual in the species, - not narrowly branched as in Meunier's figure or unbranched as in Handlirsch's. CuP and IA are close together, as usual, not widely separated as represented by Meunier. This specimen is clearly dawsoni and since the costal margin is straight (not curved as in Meunier's figure), it is almost certainly a hind wing.

Specimens studied: The following is a list of the specimens of dawson $i$ which are now known and which I have been able to examine. In the Muséum National, Paris; ( I), no. 36-5, the holotype of dawsoni, consisting of a nearly complete fore wing and two overlapped hind wings. (2), no. 36-7 (type of picta Handl.), distal two-thirds of a hind wing. (3), no. 36-8 (syntype of major Handl.), a nearly complete insect, with the fore wings overlapped and the hind wings also overlapped; some parts of thorax and legs. (4), no. 36-9 (type of longicornis Handl.), a wing base, parts of thorax, legs and antennae. (5), no. 36-1o (type of robusta Handl.), wing bases, portions of thorax, legs, antennae. (6), no. 36-I I (syntype of major Handl.), nearly complete fore wing, basal third of hind wing, parts of thorax and legs. (7), no. $\mathrm{CI}_{\mathrm{I}}$, two overlapped wings, probably hind, bases absent. (8), no $\mathrm{C}_{2}$, a well preserved fore wing, showing details of fore wing and posterior margin, parts of thorax and legs. (9), no. $\mathrm{C}_{3}$, distal third of a wing, probably hind. (IO), no. $\mathrm{C}_{4}$, a very clear fore wing, and basal parts of a hind, parts of thorax and legs. (II), no. $\mathrm{C}_{5}$, basal half of a hind wing, posterior margin very clear. (I2), the type of royeri Meunier, a nearly complete hind wing, lacking only the very base. In the British Museum (Natural History), London: (13), no. I7292, consisting of at least three (probably four) overlapped wings; also parts of thorax and legs, poorly preserved. Bolton 
(1925) was in error in describing a large precostal area in this fossil; he apparently did not realize that more than two wings were overlapped, resulting in a confused jumble of veins.

\section{Apsidoneuridae, new family}

Fore and hind wings similar. Sc extending to about the apex of the wing; $\mathrm{CuA}$ and $\mathrm{CuP}$ very close together and nearly parallel; MP forked broadly and unevenly, the anterior branch (MP I +2$)$ arching strongly away from $M P 3+4 ; 3$ anal veins; cross-veins numerous. Body unknown.

This family is related to the Caloneuridae but differs in the length of Sc, the number of anal veins and the nature of the fork on MP. It is based on the type-genus Apsidoneura Carpenter (Permian, Kansas), which was originally placed in the Permian family Paleuthygrammatidae. Study of additional specimens of Caloneurodea from Permian strata of Oklahoma and of the type of similis from Commentry has led me to conclude that Apsidoneura and Homaloptila represent a distinct family.

\section{Genus Homaloptila Handlirsch}

Homaloptila Handlirsch, 1919, Denkschr. Acad. Wiss., 96:36.

Rs with four main branches, one of these usually having a terminal fork; MP $3+4$ continuing in a nearly straight line the stem MP, which arises from $\mathrm{CuA}$ at a considerable distance from the separation of $\mathrm{CuA}$ from R. In Apsidoneura, MP arises from $\mathrm{R}$ or the junction of $\mathrm{R}$ and $\mathrm{CuA}$.

Type-species: Homaloneura similis Meunier. This is the only species known in the genus.

\section{Homaloptila similis (Handlirsch) \\ Figure 2}

Homaloneura similis Meunier, 1911, Bull. Mus. Nat. Hist. Natur., 17:118, fig. 1. 1912, Annal. Paleont., $7: 8$; fig. 6 ; pl 6, fig. 5.

Homalopt la similis Handlirsch, 1919, Denkschr. Akad. Wiss. $96: 36$, fig. 42, 43.

Fore wing: length, $30 \mathrm{~mm}$., maximum width, $7 \mathrm{~mm}$. Rs with four main branches, at least two of which are forked distally. MP $\mathrm{I}+2$ arched away from MP $3+4$ as characteristic of the family, but curved strongly towards MP $3+4$ distally. There is a tendency for the formation of an irregular network of cells in the distal parts of Rs and MP. Base of wing slender but not as slender as in Apsidoneura flexa. Hind wing: similar to the fore wing in size and venation but having a straight costal margin towards the base. The venational pattern is shown in figure 2 . 
Holotype: Muséum National, Paris. This is a well preserved specimen showing a fore wing and hind wing, their bases overlapped but otherwise independent. The veins are distinct and can be clearly seen under good illumination.

Meunier's drawing of this specimen is incorrect and misleading; he completely overlooked in both wings the fork on MP and the proximity of $\mathrm{CuA}$ and $\mathrm{CuP}$. Handlirsch's drawing, based on Meunier's
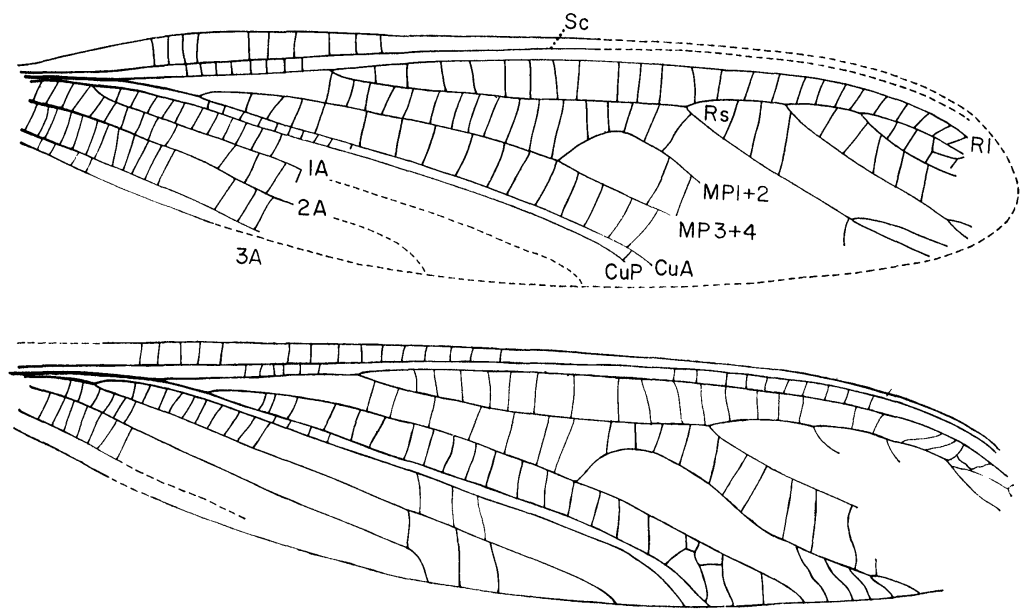

Figure 2. Homaloptila similis (Meunier). Fore and hind wing, based on holotype in Muséum National, Paris. Lettering as in figure 1.

published photograph, was equally inaccurate, showing the hind wing with a broad anal area. However, even though the wings are slightly overlapped basally, the margins of the wings are distinct.

The presence in the Commentry shales of this genus, allied to Apsidoneura, is an interesting example of a Permian element in the Commentry fauna. A similar occurrence was noted (Carpenter, 1943) in the Order Protodonata, the genus Meganeurula of Commentry being virtually indistinguishable from the Permian genus Typus.

BoltoN, H.

\section{REFERENCES}

1925. Insects from the Coal Measures of Commentry. Brit. Mus. (N. Brongniart, C.

H.), Fossil Insects, $2: 1-56$.

1885. Les insectes fossiles des terrains primaires. Soc. Amis Sci. Nat. Rouen, Bull. : 55-68. 
1894. Recherches pour servir à l'histoire des insectes fossiles des temps primaires. Thèse Fac. Sci. Paris, no. 821:1-494.

Carpenter, F. M.

1943. The Lower Permian insects of Kansas. Part 9. The Orders Neuroptera, Raphidiodea, Caloneurodea and Protorthoptera. Proc. Amer. Acad. Arts Sci., 75: 55-84.

1943. Studies on Carboniferous insects from Commentry, France. Part I. Introduction and families Protagriidae, Meganeuridae, and Campylopteridae. Geol. Soc. Amer., Bull., 54:527-554.

1951. Studies on Carboniferous insects from Commentry, France. Part Handlirsch, A. II. The Megasecoptera. Journ. Paleont., 25:336-355.

1906. Die Fossilen Insekten. Leipzig.

1919. Revision der Paläzoischen Insekten. Denkschr. Acad. Wiss. Wein, Math.-Naturwiss. Klasse, 96:1-82.

LAMEere, A.

1917. Revision sommaire des insectes fossiles du Stephanien de Commentry. Mus. Nat. Hist. Natur., Bull., 23:141-201.

Martynov, A. V.

1938a. Permian fossil insects from the Arkhangelsk district. Part V. The family Euthygrammidae and its relationships. Trav. Inst. paleontol. Acad. Sci. URSS, 7:69-80.

1938b. Etudes sur l'histoire gèologique et de phylogénie des ordres des insectes. I. Palaeoptera et Neoptera-Polyneoptera. Trans. de Meunier, F. l'Inst. Paléont., $7: 1-149$.

1911. Nouveaux insectes du houiller de Commentry. Mus. Nat. Hist. Natur., 17:117-128.

1912. Nouvelles recherches sur quelques insectes du terrain houiller de Commentry• Ann. Paleont., $7: 1-19$. 

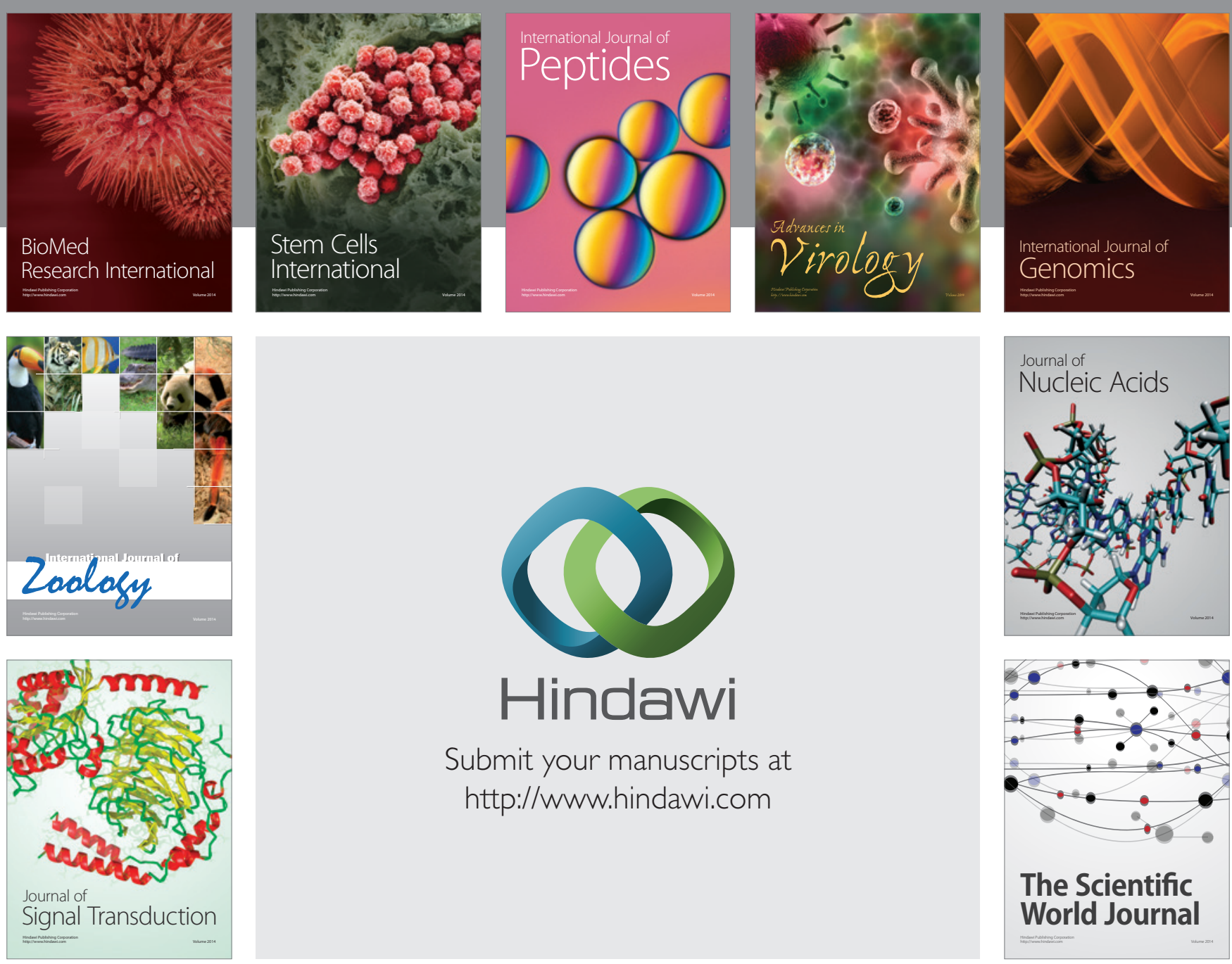

Submit your manuscripts at

http://www.hindawi.com
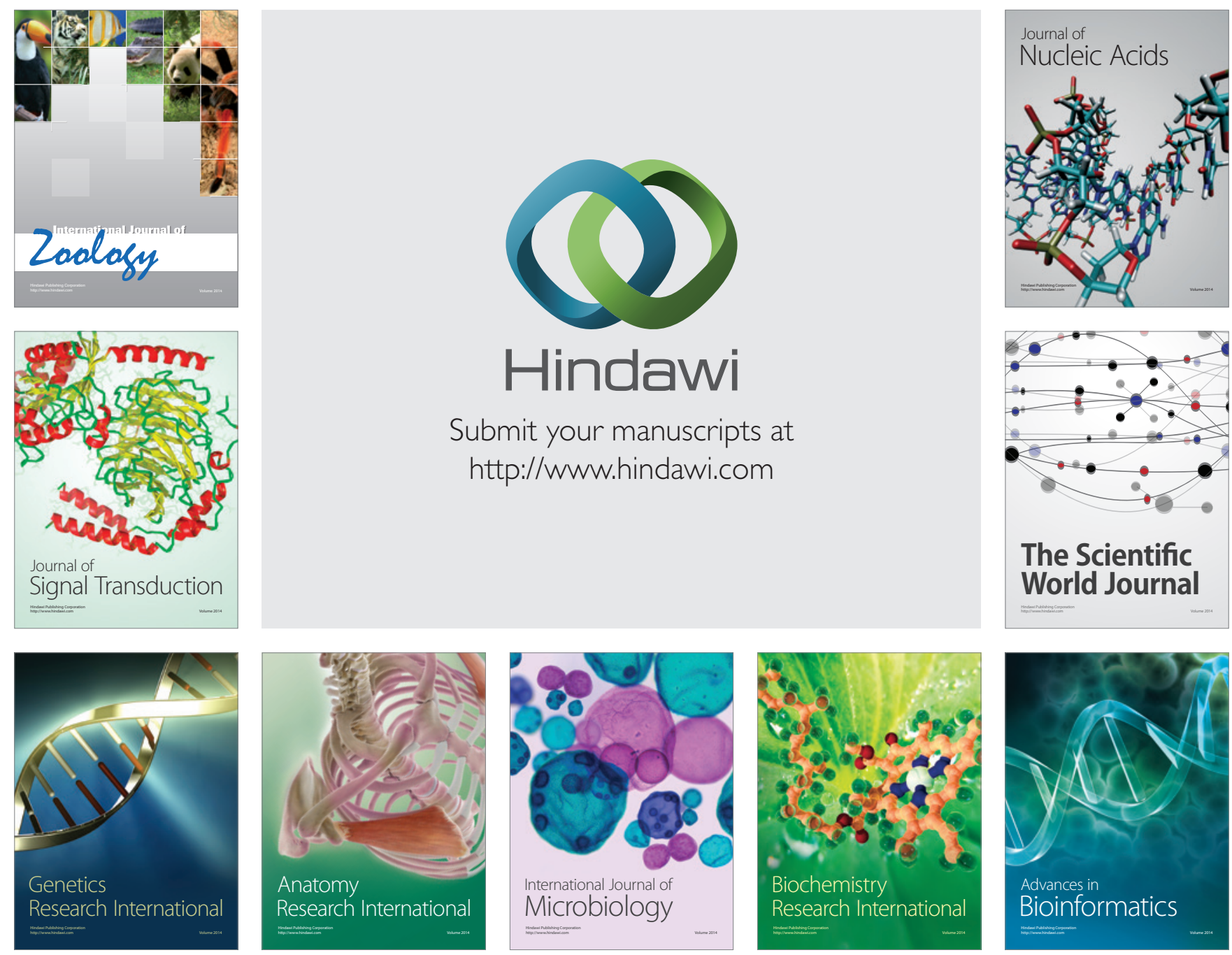

The Scientific World Journal
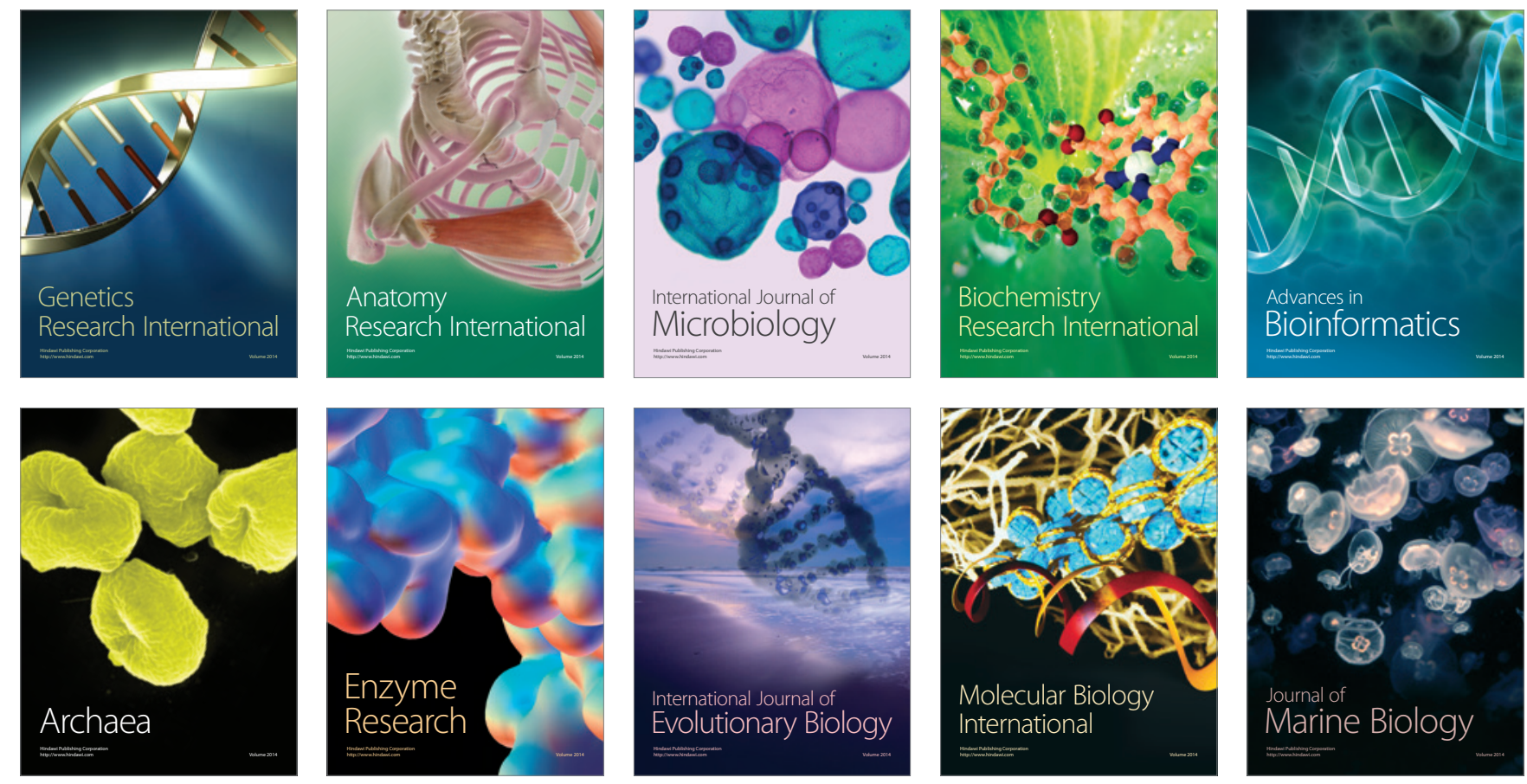